\title{
Repeated stretched or non-stretched small bowel length measurements in healthy individuals
}

\author{
Servet Karagül ${ }^{1}$, Cüneyt Kayaalp ${ }^{1}$ \\ 1 Department of Surgery, Liver Transplantation Institute, Malatya, Turkey
}

\begin{abstract}
Objective: The aim of the present study was to contribute to the establishment of a standard method of small bowel measurement by comparing repeated small bowel length measurements with and without stretching in healthy individuals.

Material and Methods: Small bowel measurement was randomly performed in 24 healthy liver donors. Three repetitive measurements were performed with complete stretching in 12 cases; whereas, 3 consecutive measurements were made without any stretching in the other 12 patients. Living donor hepatectomy continued uneventfully in all cases.

Results: In the non-stretched group, the second measurement was $199 \mathrm{~cm}$ shorter than the first measurement $(p<0.001)$. In the third measurement, this shortening had increased further, and the difference from the first measurement was $234 \mathrm{~cm}$ on average $(p<0.001)$. In the stretched group, a shortening of approximately $135 \mathrm{~cm}$ between the first and second measurements was noted. In the third measurement, an improvement of $4 \%$ was observed in contrast to the non-stretched method, with a mean reduction of $105 \mathrm{~cm}$ in the small bowel length compared with the first measurement ( $p<0.001$ ).
\end{abstract}

Conclusion: Stretching technique can reduce error rate in repeated small bowel measurements.

Keywords: Bariatric surgery, human anatomy, metabolic surgery

Cite this article as: Karagül S, Kayaalp C. Repeated stretched or non-stretched small bowel length measurements in healthy individuals. Turk J Surg 2019; 35 (1): $1-5$

\section{Corresponding Author}

Servet Karagül

E-mail: servetkaragul@hotmail.com

Received: 13.01 .2018

Accepted: 13.02 .2018

Available Online Date: 20.11.2018

( Copyright 2019 by Turkish Surgical Society Available online at www.turkjsurg.com

DOI: 10.5578/turkjsurg.4087

\section{INTRODUCTION}

Measurement of all or part of the small bowel is a common and mandatory procedure in surgeries requiring small bowel resection or anastomosis. Depending on the procedure to be performed, the length of the bowel segments to anastomose is known at the beginning of the surgery, particularly in bariatric and metabolic surgeries (1-3). However, different surgeons employ different techniques to measure these lengths, and even if the same surgical technique is applied, the efficiency of the outcome may vary. A standard technique for measuring bowel length has not been established, which presents an obstacle to achieving the desired clinical outcomes and accurately assessing postoperative complications (4-9).

The small bowel is an elastic organ. The use of different techniques involving stretching or non-stretching of the bowel during measurement suggests that the target segment for a standard surgery will, unfortunately, differ in length from surgeon to surgeon. Although bowel lengths measured with and without stretching have been reported in the literature, to our knowledge, no studies have compared the two methods. Another important consideration is that if intraoperative bowel length measurement is repeated for any reason, contraction of the bowel smooth muscle may lead to erroneous results. In this study, small bowel length measurements obtained with and without stretching in healthy individuals undergoing living donor hepatectomy were prospectively recorded and compared. The aim was to compare the results obtained from these healthy individuals in order to facilitate the establishment of a standardized method of small bowel measurement. 


\section{MATERIAL and METHODS}

Small bowel length measurements were performed in 24 healthy, prospectively enrolled and randomized liver donors at Inönü University Liver Transplant Institute. The study was approved by İnönü University Ethics Committee. Informed consent was obtained from all the individuals who participated in the study. Completely healthy liver donors $>18$ years old who had no previous abdominal surgery were included into the study. Patients who had previous abdominal surgery were excluded from the study. The distance between the Treitz ligament and the ileocecal valve was measured using a $70 \mathrm{~cm}$ nylon tape. A sterile ruler was used to measure the final loops that were $<70 \mathrm{~cm}$. All measurements were performed by the same surgeon immediately after laparotomy, before hepatectomy, or any other intra-abdominal manipulations. Twelve consecutive randomized patients were measured while fully stretching the small bowel, whereas the other 12 patients applied no tension when taking measurements. Measurements were performed at the midline between the mesenteric and antimesenteric borders and repeated three times using the same technique, resulting in three small bowel length measurements for each participant. The measurements were repeated in immediate succession. The measurement process lasted a total of approximately $10 \mathrm{~min}$, and living donor hepatectomy proceeded uneventfully after measurements of all cases.

Demographic data, bowel measurement technique used, and bowel lengths were recorded in a Microsoft Excel file.

\section{Statistical Analysis}

For homogeneous parameters, the paired Student's t-test was used for comparison of continuous variables of the same patients. For non-homogeneous parameters, the Mann-Whitney $U$ test was applied. Comparison of two continuous parameters was made by Pearson correlation coefficient. Statistical Package for Social Sciences (SPSS) version 17.0. (SPSS Inc.; Chicago, IL, USA) was used for statistical analysis. A p $<0.05$ was accepted as statistically significant.

\section{RESULTS}

There were no significant differences in demographic data, such as age, sex, height, body weight, and body mass index, in the study groups. There were no significant differences between the two groups in the first small bowel measurements. When small bowel lengths obtained in the second and third measurements were compared, the non-stretched group had significantly smaller values than the stretched group (Table 1).

In the non-stretched group, a shortening of $28.8 \pm 7.1 \%$ between the first and second measurements was observed $(p<0.001)$. The decrease was $33.7 \pm 7.7 \%$ between the first and third measurements $(p<0.001)$. The small bowel length in the third measurement was approximately $5 \%$ shorter than that in the second measurement. When the change in the second measurement (1 vs. 2) was compared with the change in the third measurement (1 vs. 3), the length continued to decrease significantly in the non-stretched group $(p=0.004)$.

In the stretched group, a shortening of $17.9 \pm 8.8 \%$ in the small bowel length between the first and second measurements was observed $(p<0.001)$. In the third measurement, the small bowel length increased again and was closer to that obtained in the first measurement. As a result, using the stretched method, a shortening of $13.8 \pm 5.6 \%$ in the third measurement compared with the first measurement was noted $(p<0.001)$. In contrast to the non-stretching technique, there was an improvement of approximately $4 \%$ in the third measurement.

When the change in the second measurement (1 vs. 2) was compared with the change in the third measurement (1 vs. 3) in the stretched group, the increase in the small bowel length reduced the statistical significance of the difference from baseline ( $p=$ 0.05) (Figure 1).

\section{DISCUSSION}

Measurement of the length of the human small bowel is not just an anatomic data point but is also important for avoiding short

Table 1. Comparison of the stretched and non-stretched groups

\begin{tabular}{|c|c|c|c|}
\hline Parameter & Stretched $(n=12)$ & Non-stretched $(n=12)$ & $p$ \\
\hline Age (year) & $25.9 \pm 7.9$ & $25.9 \pm 6.5$ & 1.00 \\
\hline Gender (male/female) & $7 / 5$ & $8 / 4$ & 0.67 \\
\hline Length (cm) & $171 \pm 11$ & $172 \pm 8$ & 0.87 \\
\hline Weight (kg) & $68 \pm 7$ & $72 \pm 12$ & 0.41 \\
\hline BMI $\left(\mathrm{kg} / \mathrm{m}^{2}\right)$ & $23 \pm 3$ & $24 \pm 3$ & 0.52 \\
\hline SBL 1 (cm) & $748 \pm 102$ & $696 \pm 112$ & 0.25 \\
\hline $\mathrm{SBL} 2(\mathrm{~cm})$ & $613 \pm 98$ & $497 \pm 105$ & 0.01 \\
\hline $\mathrm{SBL} 3(\mathrm{~cm})$ & $643 \pm 90$ & $462 \pm 92$ & $<0.001$ \\
\hline
\end{tabular}




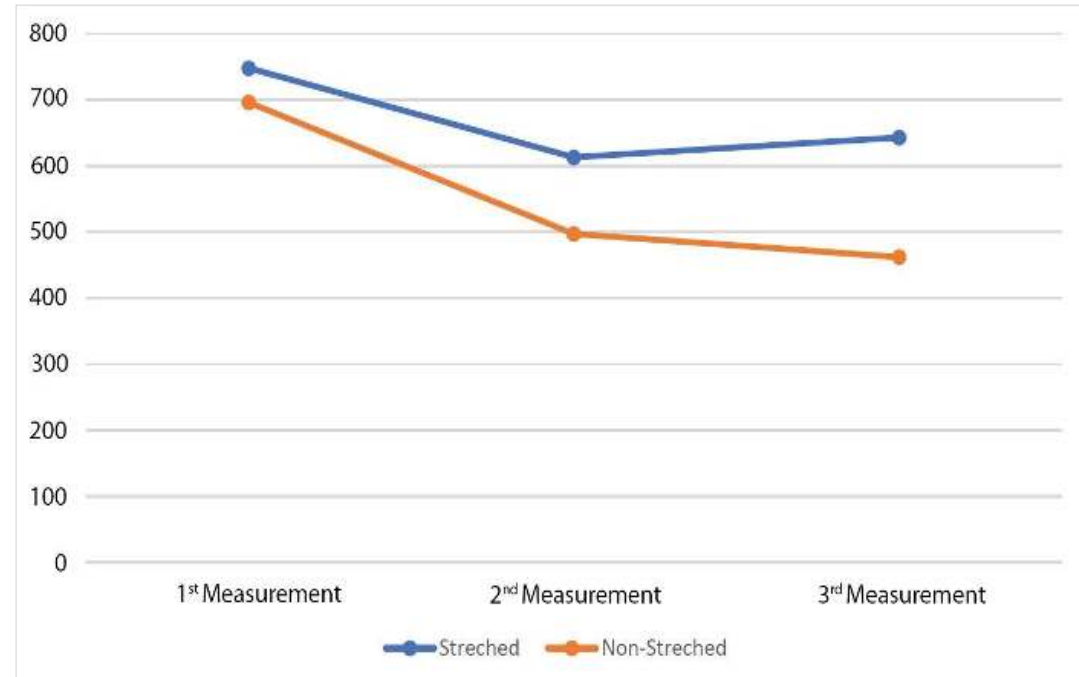

Figure 1. Consecutive small bowel length measurements in the stretched and nonstretched groups.

bowel syndrome or complications of metabolic and bariatric surgeries that may develop postoperatively. Many studies have criticized the fact that measurements cited in the literature are not obtained using a standard method. Nevertheless, there have been relatively few studies aimed at establishing standardization of measurement $(8,10,11)$. The common feature of these studies is that they were all conducted within the last few years. The momentum gained by bariatric and metabolic surgeons has shifted research in this direction.

We believe that the lack of a gold standard procedure is the main reason for this. With current surgical techniques, the length of the bowel limbs must be revised due to complications or unsatisfactory outcomes. Therefore, surgeons are more concerned with how to measure the length of bowel segments than anatomists.

The length of the small bowel has been studied for over a century, initially in cadavers. Various measurement techniques have been used in this process. The primary difference between these techniques is which contour of the small bowel is followed during measurement. The length of the small bowel can be determined based on the mesenteric border, the antimesenteric border, or the midline $(4,7,12)$. Owing to the radial anatomic structure of the small bowel, studies in which the bowel has been measured along different lines are difficult to interpret realistically. For this reason, it is important to be consistent in which aspect of the bowel is used for measurement.

We obtained measurements from the midline between the mesenteric and antimesenteric borders in the present study. It has yet to be determined in the literature which contour is optimal for conducting measurements.
Another critical point that led to the present study is the question of whether or not to stretch the bowel during measurement. Stretching the elastic small bowel segments can result in longer length values measured in the same bowel. Underhill has evaluated small bowel length measurements before and after stretching in cadavers and determined that the small bowel length is increased by $4 \%$ in bodies refrigerated for 1 to 3 days (13). Considering that stretching alters small bowel length values even in the tissue that has lost most of its elasticity and tone, this can be expected to pose an even greater challenge in the living tissue. Some studies in the literature have not addressed the issue of tension at all $(5,9,12,14)$.

A previous study has measured and compared small bowel length measured before and after stretching in the same live subjects and reported that stretching results in increases of 72 to $212 \mathrm{~cm}$ in the measured values (8). However, the authors of the previous study have overlooked the effect of repeated measurement on bowel length. In our earlier study of bowel length measurements, we demonstrated that repeated measurements yield different results, even when using the same technique (15). When a bowel segment is measured using any technique, contractions induced by manipulation change the length of the bowel prior to the subsequent serial measurement.

Therefore, repeating the measurements using different techniques, as in the study by Tacchino, compromises the validity of the length differences observed (8). The question we would like to answer is which technique will reduce the likelihood of making a surgical error when repeated measures of the bowel are required. Abellan et al. have examined the effect of the ratio of common limb length to total bowel length on clinical 
outcomes in patients with Roux-en-Y gastric bypass (16). They have measured the bowel length accurately and repeated the measurement twice each time to ensure greater reliability. In cases of discrepancy between the measurements, a third measurement has been performed. The length of the common limb has been calculated by subtracting the sum of the lengths of the biliopancreatic and alimenteric limbs from the total bowel length. However, repeated measurement performed in the present study in the name of caution was itself a source of inaccuracy. The effect of bowel contractions on measured bowel length was overlooked. Moreover, the length of the common limb was not measured directly but derived based on the total length of the other limbs. It should be recognized that the repeated small bowel length measurement process has been and will continue to be a reflection of the meticulous work of surgeons. Therefore, after each measurement of the stretched or non-stretched bowel in the present study, we repeated the measurement two more times. In order to achieve a repeatable, standardized method, we believed it would be beneficial to first evaluate the repeatability within subjects.

In both the stretched and non-stretched groups, a significant shortening of the small bowel between the first and second measurements was observed. However, the non-stretched group showed a greater reduction in length than the stretched group. Regardless of the technique, repeated measurement resulted in contractile shortening of the bowel. However, in the third measurement, this shortening continued in the nonstretched group, whereas the third value obtained in the stretched group was closer to the initial measurement. These results suggest that stretching the bowel during measurement results in more reliable length values. This information is especially valuable for surgeons today, because bowel length measurement often needs to be repeated in order to form different limbs, especially in bariatric and metabolic surgeries.

When Guzman et al. have stated that no surgeon would operate on a perfectly healthy person, they could not imagine a study where bowel length was measured in healthy subjects (17). One of the main points that make the present study valuable is that all measurements were taken from completely healthy liver donors. Furthermore, all measurements were performed by the same surgeon, thereby reducing subjective factors in the measurement technique.

\section{CONCLUSION}

In contrast to all other tissues, standardization of the technique is required for small bowel length measurement. We should keep in mind that just one touch to the small bowel will change all expected outcomes. According to our study, the stretching technique can reduce the error rate in repeated small bowel measurements.
Ethics Committee Approval: Ethics committee approval was received for this study from the Ethics Committee of Inönü University School of Medicine.

Informed Consent: Written informed consent was obtained from patients who participated in this study.

Peer-review: Externally peer-reviewed.

Author Contributions: Consept - C.K.; Design - S.K., C.K.; Supervision - C.K. Resource - S.K., C.K.; Materials - S.K., C.K.; Data Collection and/or Processing - S.K., C.K.; Analysis and Interpretation - S.K., C.K.; Literature Search - S.K., C.K. Writing Manuscript - S.K., C.K.; Critical Reviews - S.K., C.K.

Conflict of Interest: The authors have no conflicts of interest to declare.

Financial Disclosure: The authors declared that this study has received no financial support.

\section{REFERENCES}

1. Hamoui N, Anthone GJ, Kaufman HS, Crookes PF. Maintenance of weight loss in patients with body mass index $>60 \mathrm{~kg} / \mathrm{m}^{2}$ : importance of length of small bowel bypassed. Surg Obes Relat Dis 2008;4:404-6. [CrossRef]

2. Scopinaro N. Thirty-five years of biliopancreatic diversion: notes on gastrointestinal physiology to complete the published information useful for a better understanding and clinical use of the operation. Obes Surg 2012;22:427-32. [CrossRef]

3. Kao YH, LO CH, Huang CK. Relationship of bypassed limb length and remission of type 2 diabetes mellitus after Roux-en-Y gastric by-pass. Surg Obes Relat Dis 2012;8:e82-e4. [CrossRef]

4. Nordgren S, McPheeters G, Svaninger G, Öresland T, Hulten L. Small bowel length in inflammatory bowel disease. Int J Colorect Dis 1997;12:230-34. [CrossRef]

5. Hosseinpour M, Behdad A. Evaluation of small bowel measurement in alive patients. Surg Radiol Anat 2008;30:653-5. [CrossRef]

6. Teitelbaum EN, Vaziri K, Zettervall S, Amdur RL, Orkin BA. Intraoperative small bowel length measurements and analysis of demographic predictors of increased length. Clin Anat 2013;26: 827-32. [CrossRef]

7. Lohsiriwat V, Wiangphoem N, Lohsiriwat S. The length of small bowel in Thai patients. J Med Assoc Thai 2014;97:525-9.

8. Tacchino RM. Bowel length: measurement, predictors, and impact on bariatric and metabolic surgery. Surg Obes Relat Dis 2015;11:328-34. [CrossRef]

9. Hillenbrand A, Kiebler B, Schwab C, Scheja L, Xu P, Henne-Bruns D, et al. Prevalence of non-alcoholic fatty liver disease in four different weight related patient groups: association with small bowel length and risk factors. BMC Res Notes 2015;8:290. [CrossRef]

10. Muise ED, Tackett JJ, Callender KA, Gandotra N, Bamdad MC, Cowles $R A$. Accurate assessment of bowel length: the method of measurement matters. J Surg Res 2016;206:146-50. [CrossRef]

11. Gazer B, Rosin D, Bar-Zakai B, Willenz U, Doron O, Gutman M, et al. Accuracy and inter-operator variability of small bowel length measurement at laparoscopy. Surg Endosc 2017;31:4697-704. [CrossRef]

12. Koivisto $P$, Lempinen $M$, Miettinen TA. Fecal bile acids related to smallbowel length before and after ileal exclusion. Scand J Gastroenterol 1987;22:691-5. [CrossRef]

13. Underhill BML. Intestinal length in man. Brit Med J 1955;22:1243. [CrossRef]

14. Raines D, Arbour A, Thompson HW, Figueroa-Bodine J, Joseph S. Variation in small bowel length: factor in achieving total enteroscopy? Dig Endosc 2015;27:67-72. [CrossRef] 
15. Karagul S, Kayaalp C, Kirmizi S, Tardu A, Ertugrul I, Tolan K, et al. Influence of repeated measurements on small bowel length. Springerplus 2016:5:1828. [CrossRef]

16. Abellan I, Luján J, Frutos MD, Abrisqueta J, Hernandez Q, Lopez V, et al. The influence of the percentage of the common limb in weight loss and nutritional alterations after laparoscopic gastric by-pass. Surg Obes Relat Dis 2014;10:829-33. [CrossRef]
17. Guzman IJ, Fitch LL, Varco RL, Buchwald H. Small bowel length in hyperlipidemia and massive obesity. Am j Clin Nutr 1977;30:1006-8. [CrossRef]

\section{ORIIJiNAL ÇALIŞMA-ÖZET}

Turk J Surg 2019; 35 (1): 1-5

\section{Sağlıklı bireylerde tekrar edilmiş gerilimli ya da gerilimsiz ince bağırsak uzunluğu ölçümleri}

Servet Karagül ${ }^{1}$, Cüneyt Kayaalp ${ }^{1}$

${ }^{1}$ Karaciğer Transplantasyon Enstitüsü, Cerrahi Anabilim Dalı, Malatya, Türkiye

ÖZET

Giriş ve Amaç: Bu çalışmada, sağlıklı bireylerde tekrarlayan gerilimli ve gerilimsiz ince bağırsak uzunluğu ölçümleri yaparak karşılaştırdık. Amacımız, ince bağırsak uzunluğu ölçüm metodunda standardizasyon sağlanmasına katkıda bulunmaktır.

Gereç ve Yöntem: Randomize edilen 24 sağlıklı karaciğer donöründe ince bağırsak ölçümü yapıldı. On iki olguda tam gerginlik oluşturarak, 12 olguda ise gerilimsiz olmak üzere ardışık tekrarlanan uzunluk ölçümleri yapıldı. Tüm olgularda karaciğer donör hepatektomi işlemine sorunsuz devam edildi.

Bulgular: Gerilimsiz grupta ikinci ölçüm birinci ölçümden $199 \mathrm{~cm}$ daha kısa bulundu ( $p<0.001)$. Üçüncü ölçümde bu kısalma daha da artmış olup birinci ölçüm ile olan fark ortalama $234 \mathrm{~cm}$ idi ( $p<0.001)$. Gerilimli grupta birinci ve ikinci ölçüm arasında yaklaşık $135 \mathrm{~cm}$ fark vardı. Üçüncü ölçümde, gerilimsiz gruba zıt olarak \%4 oranında bir düzelme gözlendi ve birinci ölçüm ile karşılaştırıldığında ortalama kısalma $105 \mathrm{~cm}$ idi $(p<0.001)$.

Sonuç: Ince bağırsak uzunluğu ölçümünde germe tekniğinin kullanılması hata oranını azaltabilir.

Anahtar Kelimeler: Bariatrik cerrahi, insan anatomisi, metabolik cerrahi

Doi: $10.5578 /$ turkjsurg.4087 